\title{
Balkanologie
}

Balkanologie Revue d'études pluridisciplinaires

Vol. VIII, $n^{\circ} 2$ | 2004

Volume VIII Numéro 2

\section{Kronsteiner (Otto), Nichts als Namen}

Ljubljana : Evropska Založba, 2002, 159 p.

\section{Bernard Lory}

\section{OpenEdition}

\section{Journals}

Édition électronique

URL : http://journals.openedition.org/balkanologie/2043

DOI : $10.4000 /$ balkanologie.2043

ISSN : 1965-0582

Éditeur

Association française d'études sur les Balkans (Afebalk)

\section{Édition imprimée}

Date de publication : 1 décembre 2004

ISSN : 1279-7952

\section{Référence électronique}

Bernard Lory, « Kronsteiner (Otto), Nichts als Namen», Balkanologie [En ligne], Vol. VIII, n 2 | 2004, mis en ligne le 20 janvier 2010, consulté le 17 décembre 2020. URL : http://journals.openedition.org/ balkanologie/2043 ; DOI : https://doi.org/10.4000/balkanologie.2043

Ce document a été généré automatiquement le 17 décembre 2020.

(c) Tous droits réservés 


\title{
Kronsteiner (Otto), Nichts als Namen
}

\author{
Ljubljana : Evropska Založba, 2002, 159 p.
}

\section{Bernard Lory}

\section{RÉFÉRENCE}

Kronsteiner (Otto), Nichts als Namen, Ljubljana : Evropska Založba, 2002, 159 p.

1 Le linguiste autrichien Otto Kronsteiner nous fournit ici un petit livre à la fois bancal et jubilatoire. Bancal, car l'ouvrage est une mosaïque de textes et de fragments mal articulés et souvent redondants; jubilatoire, car l'auteur règle ses comptes avec verve et nous rappelle opportunément que l'étymologie est sujette à des manipulations idéologiques. L'enjeu n'est pas mince, aux yeux de l'historien, puisqu'il s'agit d'éclairer cinq siècles d'histoire obscure, entre l'effondrement de la structure impériale romaine et l'établissement de l'ordre féodal médiéval dans le secteur des Alpes orientales (Autriche et Slovénie actuelles). Les sources historiques sont rares et l'archéologie peu éclairante. La toponymie (et dans une moindre mesure l'anthroponymie) fournit alors un éclairage précieux. Kronsteiner s'oppose à une vision simpliste qui fait disparaître l'Empire romain et lui substitue un peuplement germanique s'installant dans le vide ainsi créé. La toponymie montre que la population latinisée occupait un vaste territoire et cohabita longuement avec les nouveaux venus alémaniques. Il retrace les contours d'une Ladinia submersa, dont n'affleurent plus de nos jours que les zones relictuelles des locuteurs du romanche, du ladin et du frioulan.

2 L'Empire avar, auquel étaient étroitement associés les Slaves, engloba une partie de ces territoires, ce qu'atteste la toponymie slave. Il existe donc aussi une Slovenia submersa sur la plus grande partie du sol autrichien actuel. Loin de se succéder, les peuples ont longuement cohabité sur un même territoire et pratiqué le multilinguisme. Certaines spécificités du Slovène résulteraient de cette longue cohabitation avec le ladin. Ce n'est que progressivement que la germanophonie a repoussé la ladinophonie et la slovénophonie. L'auteur dénonce les linguistes qui s'efforcent de camoufler cette réalité au prix de manipulations étymologiques. Il va même très loin puisqu'à ses yeux 
le toponyme Ostarrichi (attesté en 996, d'où la célébration bruyante du millénaire autrichien en 1996) serait en fait le slave/slovène, Ostrik, le «Mont Aigu»! Il a également le mérite de nous rappeler que la vision du monde transcrite par la toponymie est en général très simple et reflète étroitement la réalité du terrain, sans qu'il soit nécessaire de faire appel à des constructions légendaires élaborées. Le paysan appelle le ruisseau voisin Ruisseau et la montagne Montagne; ce sont les cartographes, ignorants du passé linguistique et des variantes dialectales qui sont la cause de bien des malentendus. Ce petit livre alerte et facile à lire nous rappelle que les sciences humaines forment un tout et que la linguistique, pas plus que les autres, ne saurait être une tour d'ivoire. 